\title{
Evaluation of Some Selected Heavy Metals in Groundwater from Samaru, North-western Nigeria
}

\author{
${ }^{* 1}$ Auwal Mohammed, ${ }^{1}$ Saheed Garba, ${ }^{2}$ Sule A. Abdullahi and ${ }^{3}$ Hasan U. Mohammed \\ ${ }^{1}$ Department of Agricultural and Bio-Environmental Engineering, Ahmadu Bello University, Zaria, Nigeria \\ ${ }^{2}$ Department of Water Resources and Environmental Engineering, Ahmadu Bello University, Zaria, Nigeria \\ ${ }^{3}$ Department of Agricultural and Bio-Resource Engineering, Ahmadu Bello University, Zaria, Nigeria \\ mohammedauwa196@yahoo.com I saheedgarba2020@outlook.com I \{abdummu1 I hassanusman311\}@gmail.com
}

\author{
Received: 05-JUN-2021; Reviewed: 21-JUL-2021; Accepted: 04-AUG-2021 \\ http://dx.doi.org/10.46792/fuoyejet.v6i3.655
}

\begin{abstract}
The chemical properties of selected heavy metals in groundwater from selected locations in Samaru, Zaria were determined and compared with Nigerian standards. Water samples were collected and chemical properties were determined. The Chemical properties such as Lead ( $\mathrm{Pb})$, Zinc ( $\mathrm{Zn})$, Copper ( $\mathrm{Cu}$ ), Cobalt (Co), Iron (Fe) Cadmium (Cd), Manganese ( $\mathrm{Mn}$ ), and Nickel (Ni) were determined. The chemical properties were determined following the American Public Health Association (APHA) procedure. The data were analyzed using the World Health Organization (WHO) and the Nigerian Standard of Drinking Water Quality (NSDWQ). The findings showed that Pb, Zn, Cu, Co in all the samples and $\mathrm{Fe}$ in samples $\mathrm{B}, \mathrm{D}, \mathrm{F}$, and $\mathrm{G}^{\prime}$ were within the acceptable limit. While $\mathrm{Cd}, \mathrm{Mn}$, and $\mathrm{Ni}$ in all the samples and Fe in samples $\mathrm{A}, \mathrm{C}, \mathrm{E}$, and $\mathrm{H}$ were more than the acceptable limit. Therefore, the results show that the Samaru Groundwater is not totally good for consumption since Cadmium (Cd), Manganese (Mn), and Nickel (Ni) were more than the acceptable limit. Moreover, it is recommended that urgent prevention measures should be put in place to prevent increased concentrations of $\mathrm{Cd}, \mathrm{Fe}, \mathrm{Mn}$, and $\mathrm{Ni}$ as a result of anthropogenic activities.
\end{abstract}

Keywords- Concentration, Drinking water quality, Groundwater, Heavy metals

\section{INTRODUCTION}

Safe water is a significant natural resource that is Srequired for human being for daily activities and it exists as surface, rain, or groundwater (Mohammed et al., 2020). Predominantly, most of the water sources for African countries for domestic activities are surface and groundwater (Maryam et al., 2018). The irregular supply of tap water makes Samaru dwellers over-dependent on groundwater from December to April for their domestic activities. Usually, $20 \mathrm{~L}$ of water would sell for about $\$ 20$ by water vendors. This will likely increase to $\$ 50$ per 20 L from March to April as a result of scarcity of water and increase stress on groundwater. Okonko et al., (2008) and Adelana et al., (2008) attributed the deterioration in the quality and quantity of surface water and public water supply system, in many developing countries to dependence on groundwater sources. Decline in groundwater quality in many countries is becoming a serious problem (Yang et al., 2016). Ordinarily, groundwater is supposed to be one of the freshwater sources but its quality is declining as a result of heavy metals migration into it.

Heavy metals are naturally occurring elements that have a high atomic weight and a density at least 5 times greater than that of water (Tchounwou et al., 2012). WHO (2011) define heavy metals as metallic element with an atomic weight $>40$. It also has a relatively high density and is toxic or poisonous even at low concentrations (Lenntech, 2004). They are' metals of atomic weight greater than sodium (Brewer, 1983).

\footnotetext{
${ }^{*}$ Corresponding Author

Section A- AGRICULTURAL ENGINEERING \& BIOLOGICAL SCIENCES Can be cited as:

Mohammed A., Garba S., Abdullahi S.A. and Mohammed H.U. (2021): "Evaluation of Some Selected Heavy Metals in Groundwater from Samaru, North-western Nigeria", FUOYE Journal of Engineering and Technology (FUOYEJET), 6(3), 1-4. http://dx.doi.org/10.46792/fuoyejet.v6i3.655
}

Heavy metals include lead $(\mathrm{Pb})$, cobalt $(\mathrm{Co})$, cadmium $(\mathrm{Cd})$, zinc $(\mathrm{Zn})$, mercury $(\mathrm{Hg})$, manganese $(\mathrm{Mn})$, arsenic $(\mathrm{As})$, silver $(\mathrm{Ag})$ chromium $(\mathrm{Cr})$, copper $(\mathrm{Cu})$, iron $(\mathrm{Fe})$, etc. Heavy metals may be naturally present in the earth's crust and are persistent environmental contaminants since they cannot be degraded or destroyed. Therefore, these metals to a small extent, enter the body system through food, air, and water, thus bio-accumulate over some time. (Lenntech, 2004; UNEP/GPA, 2004).

Chowdhury and Chandra, (1987) reported that some heavy metals, in small quantities, maybe good for human bodybuilding whereas, Ukah et al., (2019) reported that their excessive accumulation in the body is a big threat to human health. Although some heavy metals have bio importance as trace elements, the bio-toxic effects of many of them in human biochemistry are of great concern (Duruibe et al., 2007). Among heavy metals of particular importance to the human body, zinc is vital for male reproductive activity and balances copper in the body (Nolan, 2003). Calcium is an essential element in human metabolism, the chief element in the production of very strong bones and teeth in mammals (Duruibe et al., 2007). These elements are however harmful to the human body when exceeding the required limit.

Some of the heavy metals are toxic to a human being even at low concentrations. It has been reported by Steenland and Boffettan, (2000) and Singh et al., (2011) that exposures to $\mathrm{Pb}$ have been implicated to cause lung cancer, mental retardation in children, anemia, and kidney dysfunction. $\mathrm{Cr}$ and $\mathrm{Cd}$ have been reported to be hepatotoxic, neurotoxic, renal-toxic, and carcinogenic (Jarup et al., 2000; Martin and Griswold, 2009). Zn at high concentration obstruct respiratory function (Cooper, 2008). 
Therefore, heavy metal pollution has been considered a serious environmental health issue due to its toxicity even at low concentration, persistence, and bioaccumulation potential (Olagunju et al., 2020). The higher the heavy metal concentrations are, the higher their contribution to the deterioration of water resources and the environment. Once water resources and the environment are contaminated with excess heavy metals, health risks, and hazards become inevitable (Ukah et al., 2019). Since in Nigeria, the number of diseases caused by heavy metals is on increase, it is important to check the status of surface and groundwater intermittently, for monitoring and prevention of health hazards. This research aims at determining the concentration of some selected heavy metals in Samaru, Zaria Groundwater and compare them with NSDWQ.

\subsection{StUdy AREA}

Samaru is part of the Zaria urban setting. It lies within latitudes $11^{\circ} 06^{\prime} \mathrm{N}$ and $11^{012} \mathrm{~N}$ of the equator and longitude $7^{039} \mathrm{E}^{\prime}$ and $7^{0} 45^{\prime} \mathrm{E}$ of the Greenwich meridian. Samaru is located at the central high plain of Northern Nigeria at a height of about 670 meters above sea level. It is located in Sabon Gari Local government area and it is bounded to the North and North-East by Bassawa military cantonment, to the South by Ahmadu Bello University (ABU) main campus, and to the West by Division of Agricultural Colleges, the area shaded with red color in Fig. 1 indicate the study area with red color. Samaru is one of the suburbs of Zaria which is made up of distinct loosely coordinated units (Mortimore, 1970).

\section{Methodology}

The research commences with a preliminary site investigation so as to understand the study area and activities taking place there. The study area was divided into eight. In each location, one water sample was collected from a borehole or open well with a one-liter sample container. And the location coordinates were determined with GPS (global positioning system). The water samples were collected on the $29^{\text {th }}$ of March, 2021. Moreover, the sample containers were washed with detergent, rinsed with distilled water, then with spirit, and finally with distilled water. The sample containers were further rinsed two times with the water sample at each sampling point collection. During the collection, no floating object was allowed to enter the bottle. The samples were taken to Multi-User Science Research Laboratory Ahmadu Bello University, Zaria for laboratory analysis of some selected heavy metals.

Moreover, the types of samples collected with their location are shown in Table 1 . We were unable to measure the depth of the boreholes due to the unavailability of the appropriate measuring instrument.

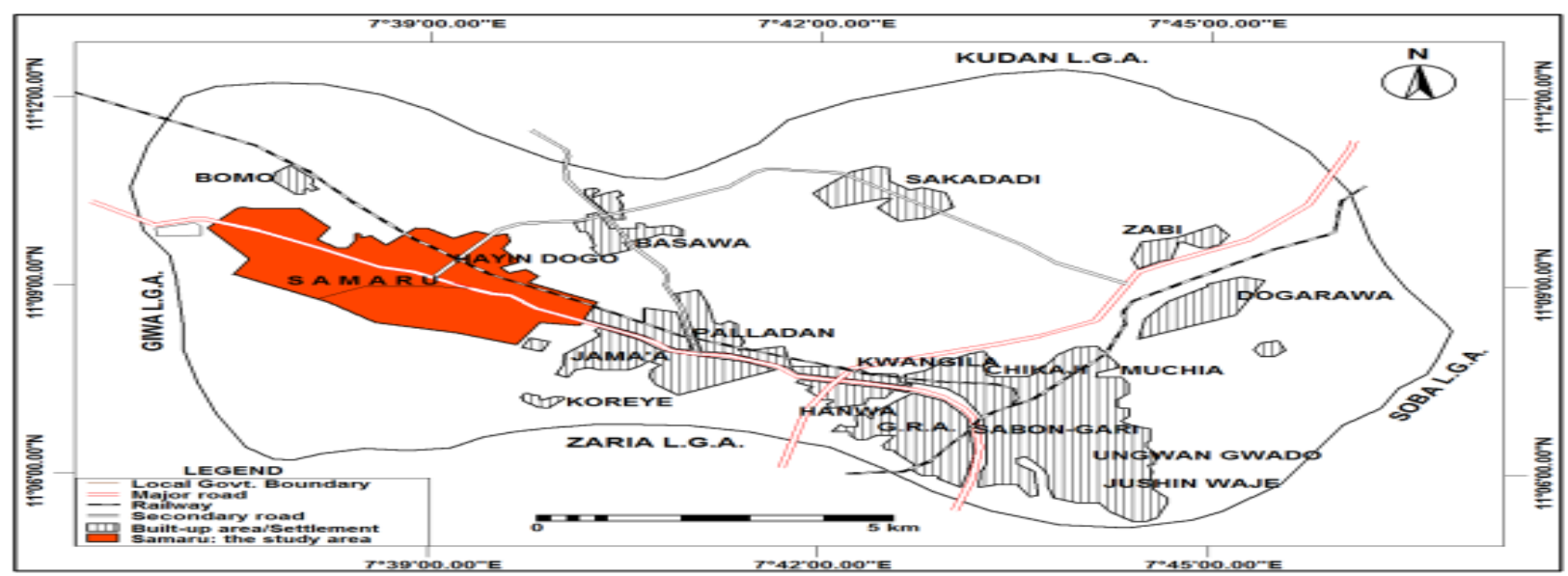

Fig. 1: map of Sabon Gari Local Government Area showing the Study Area (Source: Okpanachi, 2015)

Table 1. Samples collection and locations (Source: Fieldwork, 2021)

\begin{tabular}{|c|c|c|c|c|}
\hline \multirow[b]{2}{*}{ Samples } & \multirow[b]{2}{*}{ Types } & \multirow[b]{2}{*}{ Depth (m) } & \multicolumn{2}{|c|}{ GPS location } \\
\hline & & & Latitude & Longitude \\
\hline $\mathrm{A}$ & Open well & 3 & $11^{09} 49.59972^{\prime \prime} \mathrm{N}$ & $7^{0} 38^{\prime} 31.54884^{\prime \prime} \mathrm{E}$ \\
\hline $\mathrm{B}$ & Open well & 8 & $11^{09} 42.34824^{\prime \prime} \mathrm{N}$ & $7^{0} 38^{\prime} 53.55924^{\prime \prime} \mathrm{E}$ \\
\hline $\mathrm{C}$ & Borehole & - & 1109'37.3525" E & 7039'8.53632" E \\
\hline $\mathrm{D}$ & Borehole & - & $11^{09} 32.00696^{\prime \prime} \mathrm{N}$ & $7^{039} 20.18044^{\prime \prime} \mathrm{E}$ \\
\hline$E$ & Open well & 8 & $11^{09} 35.17596^{\prime \prime} \mathrm{N}$ & 7039'39.73060" E \\
\hline $\mathrm{F}$ & Borehole & - & $11^{09} 41.73768^{\prime \prime} \mathrm{N}$ & $7^{0} 39^{\prime} 19.18548^{\prime \prime} \mathrm{N}$ \\
\hline G & Borehole & - & $11^{09} 11.19416^{\prime \prime} \mathrm{N}$ & 7039'21.18384" E \\
\hline $\mathrm{H}$ & Borehole & - & $11^{09} 46.40812^{\prime \prime} \mathrm{N}$ & $7^{03} 9^{\prime} 13.21857^{\prime \prime} \mathrm{N}$ \\
\hline
\end{tabular}




\subsection{Laboratory Analysis of Heavy Metals}

For sample digestion, $0.5 \mathrm{~g}$ of the sample was collected and transferred to beaker. Then $2.5 \mathrm{ml}$ of $\mathrm{HCl}$ and $7.5 \mathrm{ml}$ $\mathrm{HNO}_{3}$ were added to the beaker. The mixture was put on a hot plate, at $100^{\circ} \mathrm{C}$ it was removed and allowed to cool. Waterdrop was added to it. After digestion, the concentration of heavy metals $(\mathrm{Pb}, \mathrm{Zn}, \mathrm{Cu}, \mathrm{Co}, \mathrm{Cd}, \mathrm{Fe}, \mathrm{Ni}$, and $\mathrm{Mn}$ ) from each of the filtered samples were determined using atomic absorption spectrophotometer (AAS) model AA500 at the Multi-User Science Research Laboratory, Ahmadu Bello University, Zaria. The laboratory procedures for sample analysis following American Public Health Association (APHA 2005) procedure.

\section{RESULTS AND DISCUSSION}

The concentration of chemical properties of water for samples A-H are represented in Table 2. Column 2 in the table represents the World Health Organization maximum permitted limit for drinking water of heavy metals while column 3 represents the Nigerian Standard for drinking-water quality maximum permitted limit of heavy metals. It was observed from the table that Lead $(\mathrm{Pb})$ was below the detection limit since its concentration is $0 \mathrm{mg} / \mathrm{L}$ in all the samples. This might be because there is no $\mathrm{Pb}$ mining taking place in the study area.

From all the samples Zinc $(\mathrm{Zn})$ is below the acceptable limit. Also, Copper $(\mathrm{Cu})$ is within the maximum permitted limit in the samples. It was observed from the table that $\mathrm{Zn}$ and $\mathrm{Cu}$ concentrations in sample A were higher than the remaining samples. This shows that sewage dumping site that is about $4 \mathrm{~m}$ from the shallow well contributes to the increased percentage of the elements in the well.

However, it was reviewed by Beyene and Berhe (2015) that the World Health Organization (WHO) maximum permissible limit of Cobalt (Co) for drinking water is 0.005 $\mathrm{mg} / \mathrm{L}$, therefore it is realized from Table 2 that Co concentration in sample D is within the acceptable limit while in the other samples there were not Co in present. Therefore, base on $\mathrm{Pb}, \mathrm{Zn}, \mathrm{Cu}$, and $\mathrm{Co}$ the water is very good for drinking since the elements were within NSDWQ and WHO standards for drinking water. Well, the results obtained were Agreed with Adesakin (2020) that the Chemical properties of the underground water from the Samaru community were within WHO and NSDWQ standards.

Moreover, Table 2 shows that Iron (Fe) was below the detection limit in samples $B, D, F$, and $H$ but the concentration of Fe in samples A, C, E, and G were more than the acceptable limit. The high value of Fe in sample $\mathrm{H}$ might be as a result of leaching to the groundwater from the burial ground (cemetery) since the graveyard is not far from the borehole $\mathrm{H}$ (about $250 \mathrm{~m}$ from the graveyard). Okpanachi, (2015) had earlier reported that if an urgent step is not taken on the dumpsites, the heavy metal will continue to leach into the groundwater thereby contaminating the groundwater.

It was also observed from Table 2 that the concentration of Cadmium (Cd), Manganese (Mn), and Nickel (Ni) in all the samples were more than NSDWQ permitted limit. Therefore, concerning $\mathrm{Cd}, \mathrm{Ni}$ and $\mathrm{Mn}$ the water is not safe for consumption. NSDWQ (2007) reported that Cd, Mn, and $\mathrm{Ni}$ present in water more than the recommended limit are toxic to the kidney, causing neurological disorder and carcinogenic respectively. Never the less the results obtained were agreed with what Okpanachi (2015) found that as a result of the high concentration of some heavy metals, the Samaru Groundwater is not totally safe for consumption.

Table 2. Concentration of Chemical properties of water samples at selected locations in the study areas

\begin{tabular}{|c|c|c|c|c|c|c|c|c|c|c|}
\hline \multirow[b]{2}{*}{ } & \multirow[b]{2}{*}{$\begin{array}{l}\text { WHO Maximum } \\
\text { permitted (mg/L) } \\
\text { (source: Beyene } \\
\text { and Berhe, } 2015 \text { ) }\end{array}$} & \multirow{2}{*}{$\begin{array}{c}\text { Maximum } \\
\text { permitted } \\
(\mathrm{mg} / \mathrm{L}) \\
\text { (source: } \\
\text { NSDWQ, } \\
2007 \text { ) }\end{array}$} & \multicolumn{8}{|c|}{ Samples (mg/L) } \\
\hline & & & A & B & $\mathrm{C}$ & D & $\mathbf{E}$ & $\mathbf{F}$ & G & $\mathbf{H}$ \\
\hline $\mathrm{Pb}$ & 0.01 & 0.01 & 0 & 0 & 0 & 0 & 0 & 0 & 0 & 0 \\
\hline $\mathrm{Zn}$ & 3 & 3 & 0.260 & 0 & 0.53 & 0.223 & 0.288 & 0.472 & 0.425 & 0.115 \\
\hline $\mathrm{Cu}$ & 2 & 1 & 0.235 & 0.185 & 0.130 & 0.020 & 0.165 & 0.120 & 0.175 & 0.195 \\
\hline $\mathrm{Cd}$ & 0.005 & 0.003 & 0.150 & 0.130 & 0.190 & 0.175 & 0.185 & 0.195 & 0.135 & 0.220 \\
\hline $\mathrm{Fe}$ & 0,3 & 0.3 & 0.562 & 0 & 3.020 & 0 & 1.530 & 0 & 0 & 7.00 \\
\hline $\mathrm{Mn}$ & 0.4 & 0.2 & 0.59 & 1.28 & 0.645 & 0.475 & 0.500 & 0.450 & 0.630 & 0.730 \\
\hline $\mathrm{Co}$ & 0.005 & - & 0 & 0 & 0 & 0 & 0.005 & 0 & 0 & 0 \\
\hline $\mathrm{Ni}$ & 0.02 & 0.02 & 1.573 & 1.550 & 0.875 & 0.870 & 1.220 & 0.875 & 0.985 & 0.965 \\
\hline
\end{tabular}




\section{CONCLUSION}

The chemical properties of water samples were analyzed. The results showed that the water is safe for consumption in terms of $\mathrm{Pb}, \mathrm{Zn}, \mathrm{Cu}$, and Co because they agreed with NSDWQ permitted limit. But the concentration of $\mathrm{Fe}, \mathrm{Cd}$, $\mathrm{Mn}$, and $\mathrm{Ni}$ indicated that the water is not safe for consumption regards to the elements. It is therefore recommended that urgent prevention measures should be put in place to prevent increasing concentration of $\mathrm{Cd}$, $\mathrm{Fe}, \mathrm{Mn}$, and $\mathrm{Ni}$ as a result of anthropogenic activities.

\section{REFERENCES}

Adelana, S.M.A., Abiye, T.A., Nkhuwa, D.C.W., Tindinugaya, C. and Oga, M.S. (2008). Urban groundwater management and protection in SubSaharan Africa. In: Adelana, S.M.A, MacDonald, A.M. Applied groundwater studies in Africa, International Association of Hydrogeologists, selected papers, 222-259

Adesakin, T. A. (2020). Assessing the Physico-chemical Properties and Microbiological Quality of Underground Waters (Hand-dug Well and Borehole Waters) in Samaru Community, Zaria, Northcentral Nigeria. Journal of Applied Sciences and Research, 1(1): $7-18$

APHA. (2005). Standard methods for the examination of water and wastewater (21st ed.). Washington DC: American Public Health Association

Beyene, D. H. and Berhe, B. G. (2015). The Level of Heavy Metals in Potable Water in Dowhan, Erop Wereda, Tigray, Ethiopia. Journal of Natural Sciences Research, 5(3): 190-194.

Brewer, M. (1983). Concise Encyclopedia of Biochemistry. Walter de Gruyter, Berlin, New York. pp. 1-50

Chowdhury, B. A., and Chandra, R. K. (1987). Biological and Health Implications of Toxic Heavy Metal and Essential Trace Element Interactions. Progress in Food Nutrition Science, 11(1), 55-113

Cooper, R.G. (2008). Zinc Toxicology following Particulate Inhalation. Indian J Occup Environ Med, 12: 10-13

Duruibe, J. O., Ogwuegbu, M. O. C. and Egwurugwu, J. N. (2007). Heavy Metal Pollution and Human Biotoxic Effects. International Journal of Physical Sciences, 2 (5): 112-118,

Jarup, L., Hellstrom, L., Alfven, T., Carlsson, M.D., Grubb, A., et al. (2000). Low-Level Exposure to Cadmium and Early Kidney Damage: the OSCAR study. Occup Environ Med 57: 668-672

Lenntech Water Treatment and Air Purification (2004). Water Treatment. Published by Lenntech, Rotterdamseweg, Netherlands.

Martin, S. and Griswold, W. (2009). Human Health Effects of Heavy Metals. Centre for Hazardous Substance Research. Kansas State University Manhattan

Maryam, I.S., Omoniyi, K.I. and Zaharaddeen, N.G. (2018) Determination of concentrations and Annual Effective Dose of $\mathrm{Pb}, \mathrm{Cr}, \mathrm{Rn}$ in Groundwater Sources in Shika and Zaria City, Kaduna State, Nigeria. J. Appl. Sci. Environ. Manage, 22 (5): 659 666.

Mohammed, A., Musa, Y.M. and Naziru, H. (2020). Determination of Physicochemical and Bacteriological Quality of Water for Irrigation Purpose: A Case Study of Shika Dam, Zaria, Kaduna State, Nigeria. Nigerian Research Journal of Engineering and Environmental Sciences, 5(1): 198-204

Mortimore, M.J. (1970). Zaria and its Region: A Nigeria Savanna City and its Environment. Geographical Association of Zaria, Zaria Nigeria Occasional paper No. 4.

NSDWQ (2007). Nigeria Standard for Drinking Water Quality, Nigeria Industrial Standard, Approve by Standard Organization of Nigeria Governing Council. ICS 13. 060. 20: 1-30
Nolan K (2003). Copper Toxicity Syndrome, J. Orthomol. Psychiatry 12(4): 270-282.

Okonko, I.O., Adejoye, O.D., Ogunnusi, T.A., Fajobi, E.A. and Shittu, O.B. (2008). Microbiological and Physicochemical Analysis of Different Water Samples Used for Domestic Purposes in Abeokuta and Ojota, Lagos Nigeria. Afr. J. Biotech, 7(5): 17-621.

Okpanachi, A. S. (2015). Effects of Solid Waste Dumpsites on Groundwater Quality in Samaru, Zaria Kaduna State, Nigeria. MSc. Thesis Department of Geography Ahmadu Bello University, Zaria, Kaduna State Nigeria pp. 1-50

Olagunju, T.E., Olagunju, A.O., Akawu, I.H. and Ugokwe, C.U. (2020). Quantification and Risk Assessment of Heavy Metals in

Groundwater and Soil of Residental Areas around Awotan Landfill, Ibadan, Southwest-Nigeria. Journal of Toxicology and Risk Assessment, 1-12

Singh, R., Gautam, N., Mishra, A., and Gupta, R. (2011). Heavy Metals and Living Systems: An Overview. Indian J Pharm, 43: 246-253.

Steenland, K. and Boffetta, P. (2000) Lead and cancer in humans: where are we now? Am J Ind Med, 38: 295-299

Tchounwou, P.B., Yedjou, C.G., Patlolla, A.K., and Sutton, D.J. (2012). Heavy Metals Toxicity and the Environment. National Institute of Health, 101: 133-164

Ukah, B. U., Egbueri, J. C., Unigwe, C. O. and Ubido, O. E. (2019). Extent of heavy metals pollution and health risk assessment of groundwater in a densely populated industrial area, Lagos, Nigeria. International Journal of Energy and Water Resources,

United Nations Environmental Protection/Global Program of Action (2004). Why The Marine Environment Needs Protection from Heavy Metals. Heavy Metals 2004, UNEP/GPA Coordination Office.

WHO (2011). Adverse Health Effects of Heavy Metals in Children. World Health Organization, Geneva.

Yang, Q.C., Wang, L.C., Ma, H.Y., Yu K., Martin, J.D. (2016). Hydrochemical Characterization and Pollution Sources Identification of Groundwater in Salawusu Aquifer System of Ordos Basin, China. Environmental Pollution, 216. 